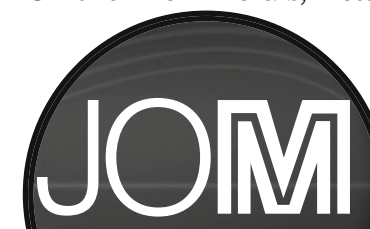
thejournal

\title{
2017 editorial calendar
}

\section{February 2017}

Theme: Production and Characterization

Application of Advanced Characterization Techniques for Engineering Materials

Advanced Characterization of Interfaces and Thin Films

Minor Elements in Metal Production

Aluminum: Bauxite-Alumina-Carbon-Reduction

Manuscripts Due: September 1, 2016

\section{March 2017}

Theme: Additive Manufacturing

Progress in Additive Manufacturing

- Processing-Microstructure-Property Relations in Additive

Manufactured Materials

- Functional Nanomaterials: Emerging Nanomaterials and Techniques for 3D Architechtures

2016 Solid Freeform Fabrication Symposium

Manuscripts Due: October 1, 2016

\section{April 2017}

Theme: Materials Processing

Aluminum: Shaping and Forming

Sintering and Related Phenomena

Behavior of Sheet Metal Under Multi-Axial Deformation Paths

Characterization and Processing of Advanced Porous Materials

Manuscripts Due: November 1, 2016

\section{May 2017}

Theme: Design and Manufacturing

Advances in Polycrystal Plasticity Characterization and Modeling

Advances in ICME Implementation: Concepts and Practices

Lightweighting

Manuscripts Due: December 1, 2016

\section{June 2017}

Theme: Progress in Materials Science

Use of Gases in Pyrometallurgy

Amorphous Alloys: Liquids and Glasses as Pathways to New Materials

Recent Progress with Lead-Free Solder Interconnects

Manuscripts Due: January 1, 2017

\section{July 2017}

Theme: Functional Materials

Micromagnetics Modeling and Simulation for Soft and Hard Magnetic Materials

Materials in Medicine and Bioengineering

Nanostructured Surfaces for Improved Functional Properties

Manuscripts Due: February 1, 2017

\section{August 2017}

Theme: Extreme Environments

Phase Transitions in Energy-Related Magnetic Materials

Corrosion of Magnesium in Multimaterial Systems

U-Mo Monolithic Fuel for Nuclear Research and Test Reactors

Stress Corrosion Cracking of Metals

- Solidification Behavior in Reduced Gravity

Manuscripts Due: March 1, 2017

\section{September 2017}

Theme: Environment and Recycling

Sustainability Indicators for Energy Systems and Technology

Deriving Value from Resource Recovery at Multiple Materials Scales

Aluminum: Recycling and Environmental Issues

Carbothermic Reaction

Manuscripts Due: April 1, 2017

\section{October 2017}

Theme: Metallurgy and Processing

Energy Technologies in Ironmaking and Steelmaking

Recent Advances in Titanium Metal and Alloy Production

- Hydrometallurgical and Electrometallurgical Processing

for Strategic Materials

- Latest Developments in Refractory Metals and Alloys

Manuscripts Due: May 1, 2017

November 2017

Theme: High-Entropy Alloys

Progress in High-Entropy Alloys

Beyond Indentation Hardness and Modulus: Recent Advances in

Nanoindentation Techniques

Nanostruc 2016

Manuscripts Due: June 1, 2017

\section{December 2017}

Theme: Energy Applications

Field-Intensified Metallurgy

Advanced Materials for Energy Applications

Thermal Energy Storage and Applications

Nanoscience for Renewable Energy

Aluminum: Cast Shop and Alloys

Manuscripts Due: July 1, 2017 


\section{advisors and guest editors}

Philip Eisenlohr

Advanced Characterization, Testing

\& Simulation Committee

Michael C. Gao

Alloy Phases Committee

Dmitry Eskin and Pascal Lavoie Aluminum Committee

Tolou Shokuhfar

Biomaterials Committee

Fadi Abdeljawad and Stephen Foiles

Chemistry \& Physics of Materials Committee

Muralidharan Paramsothy

Composite Materials Committee

Bala Radhakrishnan

Computational Materials Science

\& Engineering Committee

Srujan Rokkam

Corrosion \& Environmental Effects Committee

Christopher Gourlay

and Babak Arfaei

Electronic Packaging \& Interconnection

Materials Committee

Tao Wang

Energy Committee
Xiaochuan Lu

Energy Conversion \& Storage Committee

Chantal Sudbrack

High Temperature Alloys Committee

Takanari Ouchi

Hydrometallurgy \& Electrometallurgy

Committee

Terry Wong

ICME Committee

Vineet Joshi

Magnesium Committee

Luana Caron and Orlando Rios

Magnetic Materials Committee

Jian Li, Jian-Yang Hwang, Bowen Li, Sergio N. Monteiro

Materials Characterization

Committee

Suveen Mathaudhu

Mechanical Behavior of Materials

Committee

Terry Xu and Jung-Kun Lee

Nanomaterials Committee

Yue Liu and Xinghang Zhang

Nanomechanical Materials Behavior Committee

Ramprashad Prabhakaran

Nuclear Materials Committee
Sundarsanam S. Babu

Phase Transformations Committee

Ma Qian

Powder Materials Committee

Laurentiu Nastac

Process Technology \& Modeling

Committee

Zhiwei Peng, Jesse White, and

Dean Gregurek

Pyrometallurgy Committee

Mingming Zhang, Xiaofei Guan, John Howarter, and Randy Kirchain

Recycling \& Environmental

Technologies Committee

Ravi K. Enneti

Refractory Metals \& Materials Committee

Kester Clarke

Shaping \& Forming Committee

Mohsen Asle Zaeem, Amber Genau

Solidification Committee

Narendra Dahotre, Benjamin Boesl, and Hitesh Vora

Surface Engineering Committee

Vikas Tomar and Ritesh Sachan

Thin Films \& Interfaces Committee

Peter C. Collins and Will Joost Titanium Committee

\section{INVITED GUEST EDITORS}

Sanjit Bhowmick

Magnesium-Based Biodegradable Implants
David Bourell

2016 Solid Freeform Fabrication Symposium

Will Joost

Lightweighting
James Njuguna

Nanostruc 2016

Anyone wishing to publish in JOM should follow the guidelines established in the JOM Instructions for Authors, which features detailed information on communication, manuscript preparation, and publication procedures.

The Instructions for Authors are available on the JOM website at jom.tms.org.

For More Information Contact: Telephone: (724) 776-9000 ext. 228 e-mail: jom @ tms.org 